\title{
The Reasons of Students' Unwillingness to Receive Vocational Education
}

\author{
Nesreen Bassam Farid Fraihat \\ Part-time lecturer at the University of Jordan \\ Asma' Subhi Yousef Subuh \\ A school principal
}

\begin{abstract}
The present study aimed to explore the reasons of students' unwillingness to receive vocational education in Jordan from the perspective of faculty members. It aimed to explore whether there are statistically significant differences between respondents' attitudes which can be attributed to gender, faculty, academic rank and the country that the PhD certificate was obtained. A descriptive analytical approach was adopted. Data was collected through using a questionnaire. Questionnaire forms were distributed to (200) faculty members who work at the University of Jordan. They were selected from the faculty of educational sciences and King Abdullah II School of Information Technology. 154 questionnaire forms were retrieved. The response rate is $77 \%$. It was found that there are three types of reasons of students' unwillingness to receive vocational education in Jordan. These types are: psychological, social and economic reasons. In terms of the psychological reasons, the ones who practice a vocation do not enjoy a high job stability level. In addition, practicing a vocation requires exerting much physical effort. In terms of the social reasons, the ones who practice a vocation do not enjoy a high social standing. In addition, the opinions made by the ones who practice a vocation about daily life issues aren't taken seriously. In terms of the economic reasons, the ones who practice a vocation do not have a high\& stable income. The researchers recommend motivating students to enroll in vocational educational schools through providing them with moral and financial incentives.
\end{abstract}

Keywords: Vocational education, students, faculty members, Jordan

DOI: $10.7176 / \mathrm{JEP} / 11-4-03$

Publication date: February $29^{\text {th }} 2020$

\section{Introduction:}

There are several challenges facing the educational system in Jordan. They emerged due to experiencing global transformations and changes, such as: globalism and information technology revolution. In the light of such changes, it has become necessary to achieve development and meet the new demands and requirements. To do that, efforts must be exerted to improve the outcomes of the educational system in order to keep up with the contemporary requirements.

In order to handle the challenges facing the educational system in Jordan, there must be more attention given to the education in general and the technical \&vocational education in particular. There is a need to provide special attention to vocational education because it plays a significant role in addressing such challenges and developing the future of the country. Developing the future requires developing citizens effectively to become productive and creative citizens. The development of citizens must enable citizens to keep up with the scientific and technical developments (Abu Gazaleh and Dabour, 2002).

Vocational education plays a significant role in all countries. That is because it is connected with the labor market. It is because such education plays a significant role in developing people professionally and enabling them to participate in the achievement of social and economic development. Vocational schools are considered important institutions. For instance, they provide the labor market with qualified people who are capable of practicing vocations (Naser Allah, 2007). Al-Khateeb and Al-Khateeb (2000) add that vocational education plays a significant role in developing a labor force who are highly capable to use modern technologies and handle the rapid changes. They add that vocational education plays a significant role in developing a labor force who are capable of meeting the new demands of the labor market. Due to the significance of vocational education, some developed countries made reforms to the vocational education system. For instance, they achieved complementarily between the courses of the programs of the vocational schools. They permitted the ones who receive vocational school education to enroll in higher education institutions. They achieved consistency between vocational education and the demands of the labor market. They exerted effort in order for the vocational education to keep up with the latest scientific, cultural, social and economic changes.

It should be noted that education is considered the key for achieving development. As for the vocational training and education, they are considered the keys for making positive changes to the world of business and economy. They are the keys to fight against poverty, protect the environment, \& improve quality of life. The main goals of vocational and technical education are represented in developing people in a manner that enables 
them to join the labor market (Shamsan and Al-Heety, 1999). Education during the $21^{\text {st }}$ century aims a developing people in a manner that enables them to join the labor market. Therefore, it aims at developing students' skills and enabling them to apply their knowledge through practices. Education during the $21^{\text {st }}$ century aims at training students and enabling them to engage in real life situations. It should be noted that educational institutions have been giving priority to the development of cognitive skills over the development of manual skills. That is because economic knowledge has been playing a major role in achieving development. (Thyabat, 2005).

Technical \& vocational education have become very important during the contemporary age. Vocational education played a significant role in the ancient civilizations. However, during the last couple of decades, students have become unwilling to receive vocational education, especially in Arab countries. For instance, there are few efforts exerted in Arab countries to develop vocational education in theoretical and practical aspects (AlAjami, 2010). Therefore, there must be changes made in political and economic areas to make students willing to receive vocational education. For instance, Arab countries shouldn't reply on the foreign workers who practice vocations. For instance, there are many job opportunities in Arab countries in business, construction and vocational sectors that are given to foreign workers. Despite that, there are many local unemployed people in Arab countries. In the light of the aforementioned information, the present study aimed to explore the reasons of students' unwillingness to receive vocational education in Jordan. It aimed to explore that from the perspective of faculty of members.

Statement of the Problem:

The present study aimed to explore the reasons of students' unwillingness to receive vocational education in Jordan. It aimed to explore that from the perspective of faculty of members. There is a need to explore such reasons because such unwillingness led to having a gap between the demands of the labor market and the outcomes of the educational institutions. Due to having such a gap, there is a need to provide educational programs that utilize the potentials of human resources in a manner that meets the requirements of achieving development. Such programs are needed to handle the current and future challenges. Technical and vocational education are very important. That is because they play a significant role in achieving development in Jordan. However, there aren't many studies that shed a light on the reasons of students' unwillingness to receive vocational education in Arab countries in general and Jordan in particular. Therefore, the present study aimed to provide answers to the following questions:

Q.1. What are the reasons of students' unwillingness to receive vocational education in Jordan from the perspective of faculty of members?

Q.2 Are there statistically significant differences -at the statistical significance level of $0.05 \geq a$ - between the respondents' attitudes in this regard which can be attributed to gender, faculty, academic rank and the country that the PhD certificate was obtained from?

The Study's Objectives:

The present study aimed to explore the reasons of students' unwillingness to receive vocational education in Jordan from the perspective of faculty of members. It aimed to explore whether there are statistically significant difference - at the statistical significance level of $0.05 \geq \mathrm{a}$ - between the respondents' attitudes in this regard which can be attributed to gender, faculty, academic rank and the country that the PhD certificate was obtained from.

The Study's Significance:

The present study is significant because it aimed to identify the reasons of students' unwillingness to receive vocational education in Jordan. It is significant because it aimed to provide solutions for addressing this problem. Addressing this problem is needed due to the significance of vocational education in achieving development, and advancement. It is needed because there is a need to meet the society's needs in terms of having qualified and trained labor force. It is needed because there is a need because there is a need to narrow the gap between the outcomes of educational institutions and the demands of the labor market. It is needed because addressing this problem shall reduce the unemployment rate, develop human resources and support the national economy. The present study is significant because it is useful for:

-The Jordanian Ministry of Education and the vocational education institutions:

The present study shall encourage the latter ministry and institutions to provide much attention to vocational education. It shall encourage them to develop the labor force professionally through providing them with specialized training courses. Such courses shall develop the skills of the labor force and enable them to meet the latest demands of the labor market. Providing such courses shall participate in achieving a significant development

-Researchers:

The present study provides researchers with a theoretical framework that shall enrich the knowledge of the 
researchers who want to conduct studies about technical and vocational education. It provides researchers with a theoretical framework about the reasons of students' unwillingness to receive such education.

The Study's Variables:

The study's variables are listed below:

-Attitudes of respondents towards the reasons of students' unwillingness to receive vocational education and proposed solutions for addressing such reasons from the perspective of faculty of members

-Gender: It has two categories; male \& female

-Faculty: It has two categories; the faculty of educational sciences \& King Abdullah II School of Information Technology

Academic ranks: It has three categories; professor, assistant professor and associate professor

-The country that the $\mathrm{PhD}$ certificate was obtained from: It consists from two categories; Arab and foreign countries.

The Study's Limits:

The study's limits are listed below:

- Thematic limits: The present study aimed to identify the reasons of students' unwillingness to receive vocational education and proposed solutions for addressing such reasons from the perspective of faculty of members.

- Human limits: The population consists from all the faculty members who work at the faculty of educational sciences and King Abdullah II School of Information Technology at the University of Jordan

- Spatial limits: The present study was conducted at the faculty of educational sciences and King Abdullah II School of Information Technology at the University of Jordan

- Temporal limits: The present study was conducted during the academic year of 2019/2020

Definition of Terms:

*Technical and vocational education (theoretical definition): This expression refers to a type of formal education that is delivered by formal educational institutions. Receiving such education takes a period that is not less than 2 years. It is received after finishing the preparatory school stage. It aims at enriching students' scientific, and technical knowledge and developing students' practical skills. It aims at developing young people professionally through developing their skills and enriching their knowledge in a manner that enables them to practice a vocation and meet the requirements of practicing it (Muslim, 2007).

*Technical and vocational education (operational definition): This expression refers to a type of education that aims at developing trainees and students in order to practice manual crafts and hold non-academic jobs. In other words, it aims at developing students to become capable of practicing a specific vocation or a craft. After receiving such education, the student must acquire the required practical experience in the concerned vocation.

*Unwillingness (operational definition): It refers to the student's lack of desire to receive vocational education. The reasons of such willingness are identified through the study's instrument.

Previous Studies:

The researchers reviewed several studies which are presented below:

Al-Ulwan (2001) conducted a study titled (The difference between the vocational attitudes of the students enrolled in the vocational stream of the first secondary grade in the countryside and the city in Al-Balqa). He aimed to explore the difference between the vocational attitudes of the students enrolled in the vocational stream of the first secondary grade in the countryside and the city in Al-Balqa. He also aimed to explore the impact of (gender, parents' profession, academic achievement, parents' academic qualification, \& family monthly income) on the respondents' vocational attitudes. He aimed to identify whether there are differences between the respondents' vocational orientations during the academic year (1999/2000). It was found that respondents have positive attitudes towards vocational education. It was found that the students in the city have more positive attitudes towards vocational education than the students in the countryside. It was found that female students are more willing to receive vocational education than male students.

Vertakon \& Rousseas (2003) aimed to explore the reality of vocational education in Athens. A field investigation was conducted. It targets the vocational schools in Athens. A questionnaire was used for collecting data. It was found that vocational education is considered the last educational option for young people. It was found that the graduates of vocational schools face less difficulties than the graduates of the academic disciplines of secondary education in terms of finding a job.

Legget (2007) aimed to explore the attitudes of students, teachers, and employers towards vocational education in Mississippi. A random sample was selected. It consists from 400 individuals. It was found that students, teachers, and employers have positive attitudes towards vocational secondary school education.

Simpson (2008) aimed to conduct a comparison between students and their parents in terms of attitudes 
towards vocational education program. A random sample was selected. It consists from $1829^{\text {th }}, 10^{\text {th }}$ and $11^{\text {th }}$ grade students. It also consists from 44 female and male teachers who were selected from Dayton. A scale was used for measuring attitudes towards vocational education. It was found that the teachers working in vocational schools have positive attitudes towards vocational education. It was found that the attitudes of the latter teachers towards vocational education are more positive than the counterpart attitudes of the teachers who work in nonvocational schools. It was found that the ones who have the most positive attitudes towards vocational education are the student who participate effectively in vocational activities. It was found that the students enrolled in vocational program have more positive attitudes towards vocational education than other students.

Al-Shawabkeh et al. (2009) aimed to explore the reality of technical and vocational education in Jordan. They aimed to explore the prospects of such education in Jordan. It was found that there is a need for providing students with the skills that enable them to use modern technology. That shall enable students to participate in economic and social development and meet the society's needs. It was found that there is a need for achieving consistency between the outcomes of educational institutions and the demands of the labor market. That can be achieved through providing open learning opportunities and permitting the ones who obtained a vocational diploma degree to enroll in university. It can be achieved through encouraging students to practice self-learning to learn things about their major. That shall promote a lifelong learning approach among students. The latter consistency can be achieved through making students active learners rather than passive learners. It can be achieved through making students innovators rather than consumers of scientific innovations and modern technologies.

Halabi (2012) aimed to explore the reality of technical and vocational education in the Arab World and the problems facing such education. He targeted Syria. A field investigation was conducted in vocational schools in Edleb, Syria. Data was collected through using a questionnaire. It was found that most of the students enrolled in technical and vocational schools were not fully convinced that they should receive such schools. It was found that there isn't adequate awareness about the significance, role and meaning of technical and vocational education in developing society. It was found that curricula can significantly affect the reality of technical and vocational education.

Badrakhan (2014) aimed to explore the attitudes of tenth grade students in Jordan towards enrolling in the vocational stream of secondary school education. The sample consists from 707 female and male tenth grade students in Jordan. A descriptive analytical approach was adopted. It was found that tenth grade students in Jordan have moderate attitudes towards enrolling in the vocational stream of secondary school education. It was found that there are statistically significant differences between the respondents' attitudes in this regard which can be attributed to academic achievement. The latter differences are for the favor of the ones whose academic achievement level is moderate and the ones whose academic achievement level is low. . It was found that there are statistically significant differences between the respondents' attitudes in this regard which can be attributed to parents' academic qualification. The latter differences are for the favor of the ones whose parents hold secondary school certificate, diploma degree or BA degree.

In the light of the aforementioned studies, it can be noticed that there aren't' many studies that aimed to shed a light on the reasons of students' unwillingness to receive vocational education in Jordan. Therefore, there is a need to conduct studies about this issue. That shall participate in providing solutions for addressing such reasons

Al-Saaideh (2016) aimed to explore the reasons of students' unwillingness to receive vocational education in Jordan. He used a questionnaire to collect data from 1050 students. This questionnaire consists from 39 items. It sheds a light on several areas; economic, social, personal, vocational and educational areas. Such reasons include: the instable income of vocations and the discouragement of their peers. They include: the absence of the required physical capability. In addition, vocational education doesn't allow students to develop their capabilities and skills. It doesn't allow them to increase their knowledge. Such reasons also include: the low job security level that is associated with vocation.

Ayub (2015) aimed to explore the factors that affect students' attitudes towards vocational training and technical education. A questionnaire was used to collect data from 300 students. It was found that there are several factors that affect students' attitudes towards vocational training and technical education. Such factors include: parental influence, peers influence, socioeconomic status and career \& job potential. They also include: peer influence, parental influence, probabilities of getting a job, and socioeconomic status

The Study's Approach:

A descriptive analytical approach was adopted. This approach is considered the most suitable approach in the light of the study's goals and questions. Through adopting this approach, the researchers aimed to explore the reasons of students' unwillingness to receive vocational education in Jordan from the perspective of faculty members. The latter approach is adopted for offering readers a sensory description for objects \& items. It enables researchers to determine whether certain sensory attributes are accepted or not. It may be adopted by researchers 
to explore the nature of variables and identify the constituents of a variable (Lawless and Heymann, 1999).

The Study's Population and Sample

The population consists from all the faculty members who work at the faculty of educational sciences and King Abdullah II School of Information Technology at the University of Jordan. A random sample was selected from the population. It consists from 200 faculty members. Questionnaire forms were distributed to them 154 questionnaire forms were retrieved. The response rate is $77 \%$. All of the retrieved questionnaire forms are valid for analysis. Table (1) presents the distribution of the respondents in accordance with the personal data. Table (1): The distribution of the respondents in accordance with the personal data.

\begin{tabular}{|l|l|r|r|}
\hline Variable & Category & Frequency & Percentage \\
\hline \multirow{2}{*}{ Gender } & Male & 78 & 68.4 \\
\cline { 2 - 4 } & Female & 36 & 31.6 \\
\hline \multirow{2}{*}{ Faculty } & The faculty of educational sciences & 76 & 66.7 \\
\cline { 2 - 4 } & $\begin{array}{l}\text { King Abdullah II School of Information } \\
\text { Technology }\end{array}$ & 38 & 33.3 \\
\hline \multirow{2}{*}{ Academic rank } & Assistant professor & 52 & 45.6 \\
\cline { 2 - 4 } & Associate professor & 45 & 39.5 \\
\cline { 2 - 4 } & Professor & 17 & 14.9 \\
\hline \multirow{2}{*}{$\begin{array}{l}\text { the country that the PhD certificate was } \\
\text { obtained from }\end{array}$} & An Arab country & 66 & 57.8 \\
\cline { 2 - 4 } & A foreign country & 44 & 29.3 \\
\hline
\end{tabular}

Based on table (1), most of the respondents are males $(68.4 \%)$. It can be noticed that $31.6 \%$ of the respondents are females. It can be noticed that the number of the ones working at the faculty of educational sciences is greater than the number of the ones who work at King Abdullah II School of Information Technology. For instance, $66.7 \%$ of the respondents work the faculty of educational sciences. $33.3 \%$ of the respondents work at King Abdullah II School of Information Technology. It was found that $46 \%$ of the respondents are assistant professors and $40 \%$ of the respondents are associate professors. It was found that $15 \%$ of the respondents are professors. It was found that $66 \%$ of the respondents obtained their certificates from an Arab county and $44 \%$ of the respondents obtained their certificates from a foreign county. Thus, the number of the ones who obtained their certificates from an Arab county is greater than the number of the ones who obtained their certificates from a foreign county.

The Study's Instrument

A questionnaire was developed in order to collect data from respondents. It was developed based on the relevant references. It consists from two parts. Through the first part, the researchers aimed to collect data about the respondents' personal data. Through the second part, the researchers aimed to collect data about the reasons of students' unwillingness to receive vocational education. These reasons are classified into social, economic and psychological reasons. The five point Likert questionnaire was adopted. The greatest score in this score is 5 which is represented by (strongly agree). The lowest score in this scale is 1 which is represented by (strongly disagree)

Table (2): Categories for classifying means:

\begin{tabular}{|l|r|}
\hline Level & Range \\
\hline Low & $2.33-1$ \\
\hline Moderate & $3.67-2.34$ \\
\hline High & $5-3.68$ \\
\hline
\end{tabular}

The Instrument's Validity and Reliability

The face validity of the questionnaire was measured through passing the preliminary version of the questionnaire to a panel of experts. Those experts are faculty members who work at the University of Jordan. They are specialized in the relevant field and possess adequate expertise. They were asked to provide an assessment for the questionnaire in terms of language, clarity and relevancy. In the light of the experts' opinions, several adjustments were made to the questionnaire. Such adjustments include redrafting some statements. The reliability of the questionnaire was measured through calculating Cronbach alpha coefficient values. The total Cronbach alpha coefficient value is 0.86 . It indicates that the questionnaire is highly reliable.

Statistical analysis:

The collected data was analyzed statistically through using the SPSS program. The following statistical analysis methods were used for analyzing data:

1) The researchers calculated means and standard deviations to provide an answer to the first question 
2) The T-test for two independent samples was conducted to identify whether there are differences between the respondents' attitudes that can be attributed to gender, faculty and the country that the PhD certificate was obtained from

3) One-way analysis of variance (ANOVA) was conducted. It was conducted to identify whether there are differences between the respondents' attitudes that can be attributed to academic rank.

Results

Results related to the study's first question:

Q.1. What are the reasons of students' unwillingness to receive vocational education in Jordan from the perspective of faculty of members?

To answer this question, means and standard deviations were calculated. The answer sheds a light on social, economic and psychological areas.

First: The psychological area

Table (3): The means related to the psychological reasons of students' unwillingness to receive vocational education in Jordan from the perspective of faculty of members

\begin{tabular}{|r|l|r|r|r|r|}
\hline No. & Statement & Mean & Std. & Rank & Level \\
\hline 3 & $\begin{array}{l}\text { The ones who practice a vocation do not enjoy a high job stability } \\
\text { level }\end{array}$ & 3.52 & 0.69 & 1 & Moderate \\
\hline 2 & Practicing a vocation requires exerting much physical effort & 3.48 & 0.66 & 2 & Moderate \\
\hline 6 & $\begin{array}{l}\text { The ones who practice a vocation often do not enjoy psychological } \\
\text { comfort }\end{array}$ & 3.46 & 0.76 & 3 & Moderate \\
\hline 1 & $\begin{array}{l}\text { The ones who receive vocational education do not have a stable job } \\
\text { after gradation }\end{array}$ & 3.45 & 0.39 & 4 & Moderate \\
\hline 5 & Practicing a vocation is not considered prestigious & 3.33 & 0.64 & 5 & Moderate \\
\hline 4 & There are many physical risks associated with manual work & 3.25 & 0.45 & 6 & Moderate \\
\hline & Total & 3.28 & 0.72 & - & Moderate \\
\hline
\end{tabular}

Based on table (3), it was found that respondents have moderate attitudes towards the psychological reasons of students' unwillingness to receive vocational education. The total mean is 3.28 and the total standard deviation is 0.72 . The mean of statement (3) is ranked first and considered moderate. It is 3.52 . The latter statement states the following: (The ones who practice a vocation do not enjoy a high job stability level). The mean of statement (2) is ranked second and considered moderate. It is 3.48. The latter statement states the following: (Practicing a vocation requires exerting much physical effort)

Second: The social area:

Table (4): The means related to the social reasons of students' unwillingness to receive vocational education in Jordan from the perspective of faculty of members

\begin{tabular}{|r|l|r|r|r|r|}
\hline No. & Statement & Mean & Std. & Rank & Level \\
\hline 7 & The ones who practice a vocation do not enjoy a high social standing. & 3.36 & 0.45 & 1 & Moderate \\
\hline 10 & $\begin{array}{l}\text { The opinions made by the ones who practice a vocation about daily } \\
\text { life issues aren't taken seriously }\end{array}$ & 3.25 & 0.54 & 2 & Moderate \\
\hline 12 & $\begin{array}{l}\text { The relationship between the ones who practice a vocation are not } \\
\text { strong }\end{array}$ & 3.21 & 0.68 & 3 & Moderate \\
\hline 8 & $\begin{array}{l}\text { People underestimate the significance of the vocational secondary } \\
\text { school certificate }\end{array}$ & 3.19 & 0.87 & 4 & Moderate \\
\hline 11 & $\begin{array}{l}\text { People have feelings of disrespect to manual labor and underestimate } \\
\text { its significance }\end{array}$ & 3.17 & 0.55 & 5 & Moderate \\
\hline 9 & $\begin{array}{l}\text { Many females are unwilling to get married to the ones who practice a } \\
\text { vocation or a handcraft }\end{array}$ & 3.16 & 0.60 & 6 & Moderate \\
\hline & Total & 3.16 & 0.78 & - & Moderate \\
\hline
\end{tabular}

Based on table (4), it was found that respondents have moderate attitudes towards the social reasons of students' unwillingness to receive vocational education. The total mean is 3.16 . The mean of statement (7) is ranked first and considered moderate. It is 3.36. The latter statement states the following: (The ones who practice a vocation do not enjoy a high social standing). The mean of statement (11) is ranked fifth and considered moderate. It is 3.17. The latter statement states the following: (People have feelings of disrespect to manual labor and underestimate its significance).

Third: The economic area 
Table (5): The means related to the economic reasons of students' unwillingness to receive vocational education in Jordan from the perspective of faculty of members

\begin{tabular}{|c|c|c|c|c|c|}
\hline No. & Statement & Mean & Std. & Rank & Level \\
\hline 15 & The ones who practice a vocation do not have a stable income & 3.35 & 0.55 & 1 & Moderate \\
\hline 19 & $\begin{array}{l}\text { The ones who practice a vocation have a low income in comparison to } \\
\text { the ones who received university education }\end{array}$ & 3.29 & 0.29 & 2 & Moderate \\
\hline 21 & $\begin{array}{l}\text { There aren't many incentives given to the ones who practice a } \\
\text { vocation }\end{array}$ & 3.28 & 0.48 & 3 & Moderate \\
\hline 20 & $\begin{array}{l}\text { The ones who practice a vocation experience difficulty in getting a job } \\
\text { in the public sector }\end{array}$ & 3.26 & 0.97 & 4 & Moderate \\
\hline 23 & $\begin{array}{l}\text { The ones who practice a vocation are not provided with many } \\
\text { opportunities in terms of enrolling with higher education institutions }\end{array}$ & 3.25 & 0.39 & 5 & Moderate \\
\hline 14 & The ones who practice a vocation receive low income & 3.23 & 0.97 & 6 & Moderate \\
\hline 17 & $\begin{array}{l}\text { The incentives provided to the ones who practice a vocation are not } \\
\text { motivating }\end{array}$ & 3.22 & 0.64 & 7 & Moderate \\
\hline 24 & $\begin{array}{l}\text { The ones who practice a vocation do not enjoy a high job security } \\
\text { level }\end{array}$ & 3.21 & 0.67 & 8 & Moderate \\
\hline 18 & $\begin{array}{l}\text { The ones who practice a vocation experience a difficulty in gaining } \\
\text { money to launch his/her own business }\end{array}$ & 3.21 & 0.78 & 9 & Moderate \\
\hline 16 & $\begin{array}{l}\text { The ones who practice a vocation are not provided with guarantees } \\
\text { that ensure them that they will receive their wage in full }\end{array}$ & 3.21 & 0.91 & 10 & Moderate \\
\hline 22 & $\begin{array}{l}\text { Many employers commit infringement against the rights of the ones } \\
\text { who practice a vocation }\end{array}$ & 3.20 & 0.85 & 11 & Moderate \\
\hline 13 & $\begin{array}{l}\text { The ones who practice a vocation are forced to work overtime to } \\
\text { improve their living conditions }\end{array}$ & 3.19 & 0.98 & 12 & Moderate \\
\hline & Total & 3.21 & 0.83 & & Moderate \\
\hline
\end{tabular}

Based on table (5), it was found that respondents have moderate attitudes towards the economic reasons of students' unwillingness to receive vocational education. The total mean is 3.21 . The mean of statement (15) is ranked first and considered moderate. It is 3.35. The latter statement states the following: (The ones who practice a vocation do not have a stable income). The mean of statement (19) is ranked second and considered moderate. It is 3.29. The latter statement states the following: (The ones who practice a vocation have a low income in comparison to the ones who received university education).

Results related to the second question:

Q.2 Are there statistically significant differences -at the statistical significance level of $0.05 \geq a$ - between the respondents' attitudes in this regard which can be attributed to gender, faculty, academic rank and the country that the $\mathrm{PhD}$ certificate was obtained from?

The results related to each variable are presented below separately:

First: Gender:

Means and standard deviations are calculated to identify whether there are differences between the respondents' attitudes in this regard which can be attributed to gender. The t-test was conducted to identify whether these differences are statistically significant or not. These values are presented in table (6) below

Table (6): Means, standard deviation and the results of the T-test for identifying whether there are statistically significant differences between the respondents' attitudes in this regard which can be attributed to gender

\begin{tabular}{|l|r|r|r|r|r|r|}
\hline Gender & \multicolumn{1}{l|}{ Frequency } & Mean & Std. & T value & Sig. \\
\hline Male & 78 & 3.1 & 0.67 & \multirow{2}{*}{1.15} & \multirow{2}{*}{112} & 0.251 \\
\hline Female & 36 & 3.33 & 0.79 & \\
\hline
\end{tabular}

Based on table (6), it was found that there isn't any statistically significant difference -at the statistical significance level of $0.05 \geq \mathrm{a}$ - between the respondents' attitudes in this regard which can be attributed to gender. Second: Faculty

Means and standard deviations are calculated to identify whether there are differences between the respondents' attitudes in this regard which can be attributed to faculty. The t-test was conducted to identify whether these differences are statistically significant or not. These values are presented in table (7) below 
Table (7): Means, standard deviation and the results of the T-test for identifying whether there are statistically significant differences between the respondents' attitudes in this regard which can be attributed to faculty

\begin{tabular}{|l|r|c|c|c|l|l|}
\hline Faculty & Frequency & Mean & Std. & T value & df. & Sig. \\
\hline The faculty of educational sciences & 76 & 3.24 & 0.68 & \multirow{2}{*}{0.392} & \multirow{2}{*}{112} & \multirow{2}{*}{0.696} \\
\hline King Abdullah II School of Information Technology. & 38 & 3.18 & 0.77 & & & \\
\hline The statistical significance level is $0.05 \geq \mathrm{a}$ & & \multicolumn{5}{|l}{} \\
\hline
\end{tabular}

Based on table (7), it was found that there isn't any statistically significant difference -at the statistical significance level of $0.05 \geq a$ - between the respondents' attitudes in this regard which can be attributed to faculty.

\section{Third: Academic rank}

Means and standard deviations are calculated to identify whether there are differences between the respondents' attitudes in this regard which can be attributed to academic ranks. They are presented through table (8) below Table (8): Means and standard deviations for identifying whether there are differences between the respondents' attitudes in this regard which can be attributed to academic ranks.

\begin{tabular}{|l|r|r|r|}
\hline Rank & Frequency & Mean & Std. \\
\hline Assistant professor & 52 & 3.32 & 0.73 \\
\hline Associate professor & 45 & 3.19 & 0.69 \\
\hline Professor & 17 & 2.98 & 0.68 \\
\hline Total & 114 & 3.22 & 0.71 \\
\hline
\end{tabular}

The statistical significance level is $0.05 \geq \mathrm{a}$

Based on table (8), it appears that there are differences between the respondents' attitudes that can be attributed to academic rank. To explore the statistical significance of these differences -at the statistical significance level is $0.05 \geq \mathrm{a}$-one-way analysis of variance (ANOVA) was conducted. The results of the latter analysis are presented through table (9) below

Table (9): The results of one-way analysis of variance (ANOVA) for exploring the statistical significance of the differences between the respondents' attitudes that can be attributed to academic rank

\begin{tabular}{|c|c|c|c|c|c|}
\hline Source of variance & Sum of squares & df. & Mean of squares & F value & Sig. \\
\hline Between groups & 1.495 & 2 & 0.747 & \multirow[t]{3}{*}{1.48} & \multirow[t]{3}{*}{0.23} \\
\hline Within groups & 56.064 & 111 & 0.505 & & \\
\hline Total & 57.559 & 113 & & & \\
\hline
\end{tabular}

Based on table (9), it was found that there isn't any statistically significant difference -at the statistical significance level of $0.05 \geq \mathrm{a}$ - between the respondents' attitudes in this regard which can be attributed to academic rank

\section{Fourth: The country that the PhD certificate was obtained from}

Means and standard deviations are calculated to identify whether there are differences between the respondents' attitudes in this regard which can be attributed to the country that the $\mathrm{PhD}$ certificate was obtained from. The $\mathrm{t}$ test was conducted to identify whether these differences are statistically significant or not. These values are presented in table (10) below

Table (10): Means, standard deviation and the results of the T-test for identifying whether there are statistically significant differences between the respondents' attitudes in this regard which can be attributed to the country that the $\mathrm{PhD}$ certificate was obtained from

\begin{tabular}{|l|r|l|l|l|l|l|}
\hline Faculty & Frequency & Mean & Std. & T value & df. & Sig. \\
\hline An Arab country & 76 & 3.24 & 0.68 & \multirow{2}{*}{0.392} & \multirow{2}{*}{112} & \multirow{2}{*}{0.696} \\
\hline A foreign country & 38 & 3.18 & 0.77 & & \\
\hline
\end{tabular}

Based on table (10), , it was found that there isn't any statistically significant difference -at the statistical significance level of $0.05 \geq \mathrm{a}$ - between the respondents' attitudes in this regard which can be attributed to the country that the $\mathrm{PhD}$ certificate was obtained from

Discussion

Discussion Related to the Study's First Question:

Q.1. What are the reasons of students' unwillingness to receive vocational education in Jordan from the perspective of faculty of members?

Vocational education has been receiving much attention by the Jordanian Ministry of Education since the 1950s. That is because delivering vocational education plays a significant role in achieving economic development in Jordan. It's because delivering vocational education plays a significant role in meeting the demands of the labor market. In other words, the labor market must be provided with a workforce who are qualified in various vocations (Bader Khan, 2014). Delivering vocational education enables the government to achieve consistency 
between the demands of the labor market and the outcomes of the educational institutions. Thus, delivering vocational education has several positive impacts on Jordan. For instance, it enables the Jordanian government to meet the requirements of achieving development. Such requirements include providing the labor market with qualified labor force in various vocations (Al-Twaisi, 2016).

Although vocational education is very important, the percentage of the students who enroll in vocational schools in Jordan is low from the perspective of the faculty members. That may be attributed to the fact that vocational education programs in Jordan are not effective in meeting the goals they should meet. These goals include:instillingvocational interests within students and providing the labor market with labor force who are skillful and qualified vocationally. They also include: enabling students to use modern technologies.

Discussion Related to the Study's Second Question

Q.2 Are there statistically significant differences -at the statistical significance level of $0.05 \geq a-$ between the respondents' attitudes in this regard which can be attributed to gender, faculty, academic rank and the country that the PhD certificate was obtained from?

It was found that there isn't any statistically significant difference -at the statistical significance level of $0.05 \geq a-$ between the respondents' attitudes in this regard which can be attributed to gender, faculty, academic rank or the country that the $\mathrm{PhD}$ certificate was obtained from. That indicates that all the respondents believe that that there are psychological, social and economic reasons of students' unwillingness to receive vocational education. In this regard, the researchers didn't find any study which results are consistent or inconsistent with the latter result.

Conclusion

It was found that there are three types of reasons of students' unwillingness to receive vocational education in Jordan. These types are: psychological, social and economic reasons. In terms of the psychological reasons, the ones who practice a vocation do not enjoy a high job stability level. In addition, practicing a vocation requires exerting much physical effort. In terms of the social reasons, the ones who practice a vocation do not enjoy a high social standing. In addition, the opinions made by the ones who practice a vocation about daily life issues aren't taken seriously. In terms of the economic reasons, the ones who practice a vocation do not have a high \& stable income. It was found that there isn't any statistically significant difference -at the statistical significance level of $0.05 \geq \mathrm{a}$ - between the respondents' attitudes in this regard which can be attributed to gender, faculty, academic rank and the country that the $\mathrm{PhD}$ certificate was obtained from. In the light of the aforementioned results, the researchers of the present believe that the Jordanian Ministry of Education must develop policies for addressing the psychological, social and economic reasons of students' unwillingness to receive vocational education. They also believe that lectures must be given at school about the significance and benefits of receiving vocational education. Such lectures shall encourage students to join vocational schools.

Recommendations:

The researchers recommend the following:

1- Motivating students to enroll in vocational educational schools through providing them with moral and financial incentives. That can be done through providing students with part-time job opportunities while they are still receiving vocational school education

2- Increasing the effectiveness of the vocational education programs in meeting the intended goals. The researchers recommend making a regular assessment for such programs. They recommend finding new methods that can increase the effectiveness of the vocational education programs in meeting the intended goals.

3- Offering a variety of vocational education programs to students. That shall increase the education options available to students. The researchers recommend achieving consistency between such education and demands of the labor market. They recommend achieving consistency between such education and the practical training of the students enrolled in such programs.

References written in Arabic language

Abu Gazaleh, Haifaand Dabour, Murshed (2002). Students' attitudes towards vocational education in Jordan. Risalet Al-Mu'alem. 24(3). P.122-111

Bader Khan, Sawsan (2014). $10^{\text {th }}$ grade students' attitudes in Jordan towards enrolling in the vocational stream of secondary school education after finishing primary education. The Islamic University Journal for Psychological and Educational Studies. 22(2). 65-99

Halabi, Shadi (2012). The reality of technical and vocational education in the Arab World: A case study in the Syrian Arab Republic. Open Quds Journal for Research and Studies. P.28

Al-Khateeb, Ahmad and Al-Khateeb, Radah (2000). Modern attitudes in Training. Riyad. Al-Farazdaq AlTejareye Printing house

Naser Allah, Khalaf (2007). Vocational education in Jordan. Amman. Al-Aqsah Bookshop 
Shamsan, Ahmad and Al-Heety, Khalaf (1999). Attitudes towards technical and vocational education in Yemen. Educational Studies and Research Journal.

Al-Shawabkeh, Ali, Al-Kharabsheh, Sulaiman, and Al-Mazahreh, Ayman (2009). Technical and vocational education: reality and prospects in Jordan. The Journal of the faculty of education. Egypt. 25(2).252-252

Thyabat, Omar "Mohammad Zaki" (2005). The development of vocational training and education since the development of the Imara in 1921 till 2003. Unpublished $\mathrm{PhD}$ dissertation. Yarmouk University. Jordan

Al-Ajami, Mohammad Hasanain (2010). Modern attitudes in the light of the human development and administrative leadership. $2^{\text {nd }}$ edition. Al-Maseera Publishing and Distribution House. Jordan. Amman

Al-Ulwan, Sahar Mufleh Salem (2001). The difference between the vocational attitudes of the students enrolled in the vocational stream of the first secondary grade in the countryside and the city in AlBalqa. Unpublished MA thesis. The University of Jordan. Jordan.

Muslim, Abed Al-Qader Ahmad (2007). The reasons of vocational pressures and their impacts on technical colleges in Gaza. Unpublished MA thesis. Islamic University. Gaza

References written in English language:

- Vertakon, Vassileia, Rousseas, panagiatis, 2003, Vocational education and training in Greccr, Europ ean cevtar of development of vocational traming the ERIC Databae ED47//g

- Simpson, Willie neat. (2008). A comparison of the attitudes of pupils their parents and teachers toward the vocational education program in selected comprehensive and vocational high schools in Dayton, Ohio. (Doctoral Dissertation, University Of Cineinnati, 1976). Dissertation Abstracts International, 366056-A.

- Leggett, George (2007). Comparative study of the attitudes of selected personal in Mississippi toward secondary vocational education and the relationship of these attitudes to selected variables. (doctoral dissertation university of south Mississippi, 1978) Dissertation Abstracts International, 39,2215A.

- Al-Saaideh, Mon'im (2016). Reasons for avoidance of vocational education in Jordan. Educational Research andReviews. 11(11), pp. 1064-1084,

- Lawless H.T., and Heymann H. (1999) Descriptive Analysis. In: Sensory Evaluation of Food. Food science text series. Springer, Boston, MA

- Ayub, Hina (2015). Factors Affecting Student's Attitude towards Technical Education and Vocational Training. International Conference on Business, Economics and Management (ICBEM'2015) Dec. 15-16, 2015 Pattaya (Thailand)

Acknowledgement:

- The researchers would like to thank the University of Jordan for providing them with much support. 